\title{
The Role of Teacher Educators in Curriculum Reforms in Lesotho Schools
}

\author{
Julia Chere-Masopha, Tebello Tlali, Tankie Khalanyane and Edith Sebatane \\ National University of Lesotho, Roma, Lesotho \\ http://orcid.org/0000-0002-8279-2640 \\ http://orcid.org/0000-0003-1570-3369 \\ http://orcid.org/0000-0003-3855-4757 \\ http://orcid.org/0000-0001-9957-719X
}

\begin{abstract}
To a certain extent, many curriculum reforms that have been introduced in Lesotho schools have been unsuccessful. Teachers' preparedness to implement these reforms has been the major factor for the failures. Involving teacher education providers in the preparation of teacher preparedness could improve the success rate of these school reforms. Therefore, understanding how education educators prepare teachers for curriculum reforms could assist to understand why school teachers often appear to be ill-prepared for curriculum reforms. Accordingly, this paper investigated the views of six teacher educators about their role in the preparation of teachers for curriculum reforms in Lesotho schools. A questionnaire was used to collect data that were analysed thematically. The results obtained indicate that: teacher educators are involved in a limited way in Lesotho curriculum reforms; and they have limited knowledge about the current reforms. As a result, their training practices do not target to prepare teachers for the reforms introduced in schools. This explains why many studies have found teachers to be ill-prepared for any curriculum reforms in Lesotho. These findings raise awareness on the issue that teacher educators should be involved in the reforms in Lesotho. Therefore, the main recommendation of this study is to engage teacher education providers so as to make the reforms successful.
\end{abstract}

Keywords: curriculum reforms; teacher education providers; teacher educators; teachers' preparedness; teacher training practices

\section{Introduction and Background}

Historically, Lesotho education could be viewed as having gone through three distinctive phases of transformation, which are pre-colonial education, colonial and post-colonial education. In the third phase which is post-colonial education, different governments of Lesotho have been introducing school and curriculum reforms attempting to fix long existing problems. Some of these problems have 
been inherited from colonial education. The latest major curriculum reforms were introduced in 2009 for the purpose of changing teaching and assessment practices in Lesotho schools. However, as usual, views have already been raised regarding any successful implementation of these reforms. In particular, concerns have centred around teachers' preparedness for these reforms, with some scholars citing the role of teacher educators as preparing teachers alongside the educational needs, including educational goals and curriculum reforms of any country. With the view that teachers' ill-preparedness for addressing such needs may result from pre-service training, this paper outlines the curriculum reforms and their success in the educational system in Lesotho. The paper also examines the extent to which teacher educators may have contributed to teachers' poor implementation of the reforms. Specifically discussing teacher educators' roles, the study investigated the views of teacher educators about how they were engaged in preparing school teachers for the reforms in Lesotho.

\subsection{Pre-colonial Education}

Before the missionaries introduced Western education in Lesotho, Basotho had indigenous education system which was mainly concerned with the development and sustainability of Basotho as a nation. This type of education promoted the history of Basotho, focusing on their origin and development into a nation; cultural heritage that instilled moral and traditional values and beliefs; the development of the individual's physical character and personality, personal and family roles and responsibilities; communal life and patriotism; and the understanding of the world at large (Matšela, 1979; Ministry of Education and Training ((MOET, 2009). The recipients of this education were mainly the youth who were mostly engaged in physical and practical activities aimed at developing their knowledge and skills relevant at the time (Ansell, 2002; Education Encyclopedia, 2020; Seotsanayana \& Muzvidizwa, 2002; Selepe, 2016). Like any other indigenous African education systems, indigenous education amongst the Basotho was geared towards matching the needs and realities of the nation. Despite being mostly informal, with both teaching and learning involving observation and activity-oriented skills, the Basotho indigenous education was believed to produce well-rounded personalities groomed into fitting well in their society (MOET, 2009; Rodney et al., 1973).

\subsection{Colonial Education}

When the missionaries arrived in Lesotho in 1833, they introduced a western type education. The missionary education was offered in the formal institutions (schools) where learning took place in the classrooms and teachers acted as learning facilitators and role models of the children (Letseka, 1992). The main purpose of this education was to promote literacy, numeracy and religious values. Numeracy and literacy skills were considered valuable by the missionaries and the British Government administration (which later took over the education system). School graduates of this system could be employed as interpreters, clerks, teachers and catechists (Seotsanayana \& Muzvidizwa, 2002; Salia-Bao, 1987; Selepe, 2016). Besides the above-mentioned careers, some attention was devoted to vocational education that was designed to develop skills for domestic and construction sectors (Selepe, 2016). Emphasising European cultural interests and habits such as clothing, eating, housing and life style in general, the western 
education overlooked Basotho's norms and values (Encyclopedia, 2020; Salia-Bao, 1987) and ended up undermining Basotho's indigenous education system.

In any case, when Lesotho became the British protectorate, the British administration not only inherited the missionary education system, but they also continued to produce school graduates with only interpreting and translation skills, some of whom worked as clerks in the government administration, as teachers at church-owned schools and/or as police personnel (Seotsanayana \& Muzvidizwa, 2002). Even today, the country's education appears to be more Eurocentric than Afro-centric (Education Encyclopedia, 2020).

Generally, colonial education focused on promoting the development of the individual's physical character and personality. It emphasized foreign cultures and belief systems which resulted in graduates adopting foreign cultures and habits. On this basis, a graduate who is fluent in a foreign language and displays a European image and lifestyle has been viewed as successfully educated (Rodney et al., 1973). Perhaps, using foreign Christian names, which become key to employment opportunities has been for such reasons in Lesotho (Growth and Change in Lesotho, as cited in Seotsanayana \& Muzvidizwa, 2002).

Equally significant is that the missionary and colonial education contradicted Basotho's indigenous education by promoting foreign education systems and the culture of individualism at the cost of collective culture which was emphasised by Basotho indigenous education. Thus, the most important aspects of traditional Basotho education were downgraded and considered unimportant in the missionary and British administration education system (Thelejane, 1990). Also, the lingering outcome of the missionary and colonial education system is that technical vocational education and training (TVET) are provided under conditions which, according to the McGrath et al. (2020) and African Development Fund (2007), are so poor that even the potential employing companies do not have confidence in TVET graduates.

\subsection{Post-Colonial Education}

With the advent of independence in 1966, the government soon realised the flaws of the education system in addressing the needs of the nation. Notable was a mismatch between the education provided and employment opportunities for school graduates (Education Sector Survey Task Force Report, 1982, p.63; Encyclopedia, 2020). The successive governments of Lesotho have since then tried to 'fix' this problem through successive curriculum reforms. The first of all these curriculum reforms were carried out in 1978, followed later by the 1988 reform, and the latest being the 2009 reforms.

The 1978 National Educational Reform introduced practical subjects in schools. This reform was intended to promote the spirit of self-reliance, patriotism, respect, self-discipline and self-sacrifice by graduates (Education Sector Survey Task Force Report, 1982; Encyclopedia, 2020). It also focused on health and religious issues as well as influencing learners' attitudes towards Mathematics and Science. In 1988, another reform was introduced, the aim of which was to transform school governance and to offer education, intended to respond to the needs of the nation. 
Despite such supposedly good intensions, the 1978 and the 1988 reforms and many others that followed were not successful, particularly in relation to teaching and learning. Teaching continued to focus on promoting literacy and numeracy; and learning and passing of English as second language, science and mathematics. As a result, schools continued to produce the graduates who lacked employability skills necessary for the local and international labour markets.

More curriculum innovations were introduced through the Curriculum and Assessment Policy Framework (CAP) of 2009. These reforms aimed at revolutionizing education so that at the end of basic education, learners would have: (1) acquired reading, writing, arithmetic and life skills; (2) developed respect for environment; (3) been prepared for tertiary education and world of work; and (4) acquired personalities that have been shaped and developed in line with educational goals of the nation. Thus, as per the aims of the new reforms, the new approach to school education was to promote learners' effective communication skills; awareness of self and others; awareness of environmental adaptation and sustainable development, health and healthy living habits; and acquirement of production and work-related competencies (MOET, 2009; Raselimo \& Mahao, 2015).

The new reforms have re-arranged and organised the subjects into learning areas which are: Linguistic and Literacy; Numerical and Mathematical; Personal, Spiritual and Social; Scientific and Technological; and Creativity and Entrepreneurial. This new arrangement was expected to result in teaching and learning approaches designed to equip a learner with a body of knowledge and competencies sufficient to deal with life challenges (MOET, 2009).

The reform expected teachers to abandon their old teaching practices that fragment knowledge and teach concepts and processes of the related disciplines in isolation and to embrace teaching approaches that influence and shape learners' view of the world that: (1) the world is built of things that do not exist in isolation; and (2) there are invisible networks amongst entities that form a grand network of life. This type of teaching was expected to make learners conceptualise the world as a mighty network of multiple networks and sub-networks of relationships amongst its living and non-living, and physical and non-physical entities. Learners were also expected to appreciate the relationships amongst the elements that form these networks and the roles they play to maintain these complicated systems.

The policy (CAP) phased out subject-oriented curriculum in favour of integrated curriculum. Summative assessment practices which were mainly in a form of tests and examinations had to be abandoned in favour of continuous and formative assessments. According to this policy, teaching and assessment were not to be considered as separate: assessment was to be integral to teaching. In addition, rather than focusing on the acquirement of mere knowledge, teaching and assessment was to inform both a teacher and a leaner about the progress of a learner in acquiring new skills, attitudes and behaviour (MOET, 2009; Raselimo \& Mahao, 2015). Teachers were also to use continuous and formative assessment to generate classroom data that would inform their teaching practices. The policy also persuades teachers to use teaching strategies that integrate multiple 
disciplines; design learning tasks in such a way that, for their successful completion, would require a learner to apply knowledge from more than one discipline. Drawing on the CAP's (2009) document, such teaching strategies include project-based learning, task-oriented learning, learning portfolio and research-based learning (MOET, 2009).

\subsection{Implications on Teachers' Attributes and Practices}

The introduction of curriculum reforms in teaching, learning and assessment in schools in Lesotho had implications on the abilities of teachers who work in this system. It assumed that teachers have are able to adapt their classroom practices to the changes required by the reforms. This means that these teachers' knowledge and skills would be specialised enough to make them flexible to adopt new teaching and assessment practices. Schleicher $(2016$, p.90) defines this type of knowledge as,

"the specialized body of knowledge concerned with creating effective
teaching and learning environments for each and every student. It
includes, for example, knowledge of how to structure learning objectives,
how to plan a lesson, how to evaluate a lesson; knowledge of effective use
of allocated time and strategies for differentiated instruction; and
knowledge of how to design tasks for formative assessment. The knowledge
also includes specialized areas of "learning", such as knowing how to
facilitate learning given certain student characteristics, such as their prior
knowledge, motivation and ability levels."

The type of teachers that is required for the successful implementation of these changes should have been exposed to the similar type of curriculum implementation either through teacher education and /or in-service professional development. However, the current cohort of teachers in Lesotho schools is a product of subject-oriented teaching as learners, teacher trainees, and experienced classroom teachers. Therefore, their professional world would be defined by the type of teaching, learning and assessment that the CAP reform aimed to change. As such, teachers in Lesotho schools should have been prepared for and exposed to education and / or professional development activities that align with these new changes for successful reforms.

\section{Literature Review}

Studies have established that teachers are often expected to change their classroom practices and attitudes as a response to curriculum reforms with very limited training or preparation (Peyman et al., 2012). Nevertheless, studies by Harris \& Graham (2019), Nhlapo at el. (2019), Abraham \& Reginald (2016), and Peyman at el. (2012) have reported teachers as often ill-prepared to implement curriculum reforms, particularly reforms aimed for changing classroom practices. According to Raselimo \& Mahao (2015), inadequate training sometimes makes teachers appear to be unwilling to understand and accept the reforms, to misinterpret the reforms, and to resist to co-operate with relevant education departments. For Shankar (2014), inadequate training justifies teachers' continuity with classroom practices that mismatch the goals of the reforms. These studies have led Abraham \& Reginald (2016) and Lim \& Chan (2007) to emphasise the need for teacher education and training that targets curriculum reforms so as to 
enhance teacher participation and response. As pointed out by Lim \& Chan (2007, p.475): "Teacher education programs, especially at the pre-service stage, plays a crucial role in facilitating teachers' transformation in their instructional practices and shifting their pedagogical beliefs."

Wong (2004) observed that teacher education and training for reforms is important. Accordingly, Wong points out that for school teachers to change, teacher educators should first adopt the approaches that target curriculum reforms in their own instructional practices. It follows, therefore, that teacher education programmes should ensure that pre-service teachers develop adequate skills for relevant curriculum changes. Meaningful learning contexts should be in place to allow teachers to critically examine their own pedagogical beliefs and explore the application of the proposed changes. Without all these, school teachers are likely not to receive proper orientation and preparation for the reforms. As such, teachers would unlikely be able to implement any envisaged reforms.

\subsection{Teacher Preparation for Curriculum Reforms in Lesotho}

There is evidence that one of the key factors to the unsuccessful curriculum reforms in Lesotho schools is that teachers lack requisite knowledge and skills, and limited understanding of the reforms (Ansell, 2002; Letseka, 1992; Seotsanayana \& Muzvidizwa, 2002). Even with the newly introduced reforms (integrated curriculum and continuous and formative assessment) recent studies, such as Raselimo \& Mahao (2015), have identified the same factors. The main conclusion to be drawn from these studies is that teachers have been inadequately prepared for the implementation of the new curriculum changes.

Teacher educators are supposed to be responsible for preparing and supporting the continuous professional development of teachers (Falus \& Orgoványi-Gajdos, 2016). This means these educators should be well informed about the national educational goals and expectations for schools. As curriculum developers, they should be engaged in the development of courses that prepare teachers through professional development (Falus, \& Orgoványi-Gajdos, 2016). This means that teacher educators should collaborate with government and schools on preparing teachers for curriculum reforms. Dillon, Chang, Rondeau, \& Kim (2019) support this by indicating that where teacher educators are integrated in the curriculum initiatives they change their practices. However, as observed by Lunenberg et al. (2014) and Kosnik \& Beck (2008), this rarely happens. The authors have observed lack of collaboration relating to teacher development in many education systems, resulting in disjointed teacher development activities.

\section{Problem Statement}

Teacher training institutions should be playing a very important role in the preparation of teachers for innovation, either through in-service or pre-service training programmes (Osamwonyi, 2016). Logically, teacher education providers (institutions and teacher educators) should be involved in the preparation of teachers through pre-service education or in-service professional development programmes. Engaging teacher educators in the programmes that prepare teachers for curriculum reforms can enhance the success of such reforms. Failure to do this often result in teachers' ill-preparedness for the reforms. The literature reviewed in this study indicates that teachers have been ill-prepared for 
curriculum reforms in Lesotho. As such, knowing how and why these teachers are often ill-prepared for curriculum reforms would be important for the success of any imminent curriculum reforms.

The purpose of this study, therefore, was to investigate how teacher educators have been involved in the preparation of teachers for curriculum reforms in Lesotho schools; and how their involvement has contributed to the status teachers are currently in relating to the implementation of the reforms. Therefore, the main objectives of this study were to establish teacher educators': (1) knowledge about the new curriculum reforms in Lesotho schools; (2) involvement in teacher preparation for the reforms, and (3) challenges that relate to preparing teachers for the reforms; and (4) practices implications on teacher preparedness for the reforms. Thus, the four main questions which guided this study were: (1) What are the perceptions of teacher educators about how they have been involved in the curriculum reforms? (2) How does teacher educators' involvement guided them to prepare teachers for the reforms? (3) What are the challenges teacher educators experience in teacher preparation for the reforms? and (4) What are the implications on teacher preparedness?

\section{Methodology}

Premised on the interpretivist paradigm, this study adopted qualitative research approach and design, thereby selecting participants and methods for data collection and analysis as discussed in the following sections.

\subsection{Research Paradigm, Approach and Design}

The choice of qualitative research approach and methods was influenced by the interpretivist paradigm which supports the constructivist' view (Parsons, 2018). Constructivists believe that people give meanings to life depending on their experiences of interacting with their environments. As such, there is nothing like absolute truth or reality: truth or reality depends on an individual and a context (Parsons, 2018). Consistent with the qualitative approach to this study, the views of teacher educators, who have been investigated in this study about their involvement in the curriculum reforms in Lesotho, had been shaped by their individual and collective experiences from their working context. With the qualitative premise, the researchers have been able to perceive and understand the world through the eyes of the researched. The main purpose of qualitative studies is to have in-depth understanding of issues related to the phenomenon under study (Elo et al., 2014; Kahlke, 2014; Sinkovics \& Alfoldi, 2012). On this basis, the study describes, 'for deeper understanding', the views of teacher educators about how they are involved in the curriculum reforms in Lesotho, and how their involvement influence teachers' ability to respond to the classroom changes brought about by such reforms.

\subsection{Selection of Participants}

The views of six teacher educators (four females and two males) from one university in Lesotho were investigated in this study. These teacher educators were recruited on their availability to participate. Those available were working in the Department of Educational Foundations in the Faculty of Education. Their area of specialisations ranged from instructional design and clinical supervision, and educational psychology and inclusive education to educational management, 
leadership and policy studies and philosophy of education. The focus of the investigation was particularly on the involvement of these teacher educators in the preparation of school teachers for the current school curriculum reforms in Lesotho. The collection of data in this study was guided by Desimone's fivefeature model of professional development (Desimone, 2011, Desimone \& Pak, 2017). This model describes five important aspects that should be considered when preparing teachers for curriculum changes: (a) teachers should be exposed to content that focuses on the subject matter of a reform and how students learn that content. Such training or education should expose teachers to (b) active learning that gives them opportunities to observe how to implement the new changes and how learner's feedback is communicated. The model also suggests that teachers in pre-service or in-service programmes should be exposed to how to coherently (c) align teaching content, goals and learner activities with school curriculum and goals. Further, (d) teachers should be exposed to assessment strategies that provide learner feedback; and (e) they should be continually supported through collective participation and peer support. In addition, teachers' knowledge and beliefs about national and school policies and the needs of their learners should be taken into account (Carpenter \& Green, 2017). According to this model, teachers should not be exposed to a once-off education or training session; rather, it should be to a fair amount of time which could be equivalent to or more than 20 hours or 13 contact sessions. The model further proposes that even after training, teachers' knowledge and beliefs about national and school policies and learners' needs should be considered (Carpenter \& Green, 2017).

\subsection{Data Collection and Analysis}

A questionnaire was used to collect data for this study. These data were analysed thematically along the lines of Vaismoradi et al.'s model (2013). The model has four stages of data processing and analysis: initialisation, construction, rectification and finalisation. The results from this analysis including extracts from the participants' responses are presented in the next section.

\section{Presentation Interpretation and Discussion of Results}

The results in this study indicate that due to their limited involvement in the preparation for implementing the curriculum reforms, teacher educators have limited knowledge about the current curriculum reforms in Lesotho. As a result, the teaching practices of these educators are not aligned with the knowledge and skills teachers need to implement the curriculum reforms. Teacher educators, therefore, view their involvement in the reforms as crucial for preparing teachers for curriculum implementation.

\subsection{Teacher Educators' Knowledge about Curriculum Reforms in Lesotho Schools}

Generally, curriculum reforms are introduced to improve the quality or standard of education, drawing on both local and international practices by other institutions the world over. Most of the participants (5) appeared to use this general knowledge in their response to the question about their knowledge relating to the current curriculum reforms in Lesotho schools. While their responses were not specific to the Lesotho context, they were largely noted for 
justifying the introduction of the reforms. For example, one of the research informants revealed that the reforms were introduced: "to improve the standard of education in Lesotho". Realising that her response was not convincing, the participant supplemented this response by saying, "I have the impression that it was a matter of learning from what is considered to be best practice from other countries". The response of one participant was short, abrupt, disassociative, and insinuated frustration. The response of this participant was, "I don't know, the Government knows why they have introduced these reforms." This response could be seen as signifying the participant's frustration, thus, resulting in her reluctance to follow up on any curriculum reform processes in the country.

The responses of some participants (4) indicated that even though they did not know much about the reforms, they were, at least, aware that the reforms were about teaching, learning, and assessment. This was demonstrated in one participant's response who said, "I understand that the curriculum focuses on advancing an integrated approach in the teaching of school subject by grouping those subjects into major learning areas." Although the participant responded positively, the response shows that this teacher lacked comprehensive knowledge about the reforms. Another participant's response, also indicating limited knowledge about the reforms, saw reforms as specifically targeting learner assessment. This participant indicated that the reforms were intended to change the existing summative methods that relied mostly on examinations. The participant further stated that summative assessment was perceived as being responsible for high failure rates often associated with many grade repeaters and/or learner dropouts. Considering the reforms as favouring continuous assessment, this particular participant observed that, "They [the reforms] are about diverting from the exam-based assessment to continuous assessment; hassles that come with examinations including exam pressure and high failure (repetition rate) among students; to address issues of relevance; to address issues of school graduate employability". The participant further opined that the reforms were also intended to address the issue of education relevance and school graduate employability. Unlike other informants, this participant apparently had a broader perspective about the motivation for introducing the reforms.

\subsection{Involvement of Teacher Educators in School Curriculum Reforms in Lesotho Schools}

This study also found out that there was a minimal involvement of teacher educators in Lesotho school curriculum reforms. The responses of the participants (6) suggested that they had not been formally engaged in the reforms, either as teacher educators or as the Faculty of Education. Making reference to the current school reforms, this is how one of the participants put it: "There has been no involvement of any kind either directly or indirectly. The Department of Education Foundations did ask for a meeting with the Ministry Education and Training for highlights on the new curriculum, but the highlights were wanting". According to the participants (6) in this study, various departments in the Ministry of Education and Training, rather than the institutions of higher learning, have been engaged in the preparation of teachers for the new reforms. One participant indicated that the workshops to which they had been invited by the ministry departments, were mainly concerned with subject-specific areas, not about the reforms. These 
participants pointed out that even with these workshops, there is lack of clarity about the criteria used to identify those invited. This was particularly pointed out as follows by the participant:

"... not sure of the stage when they get involved. I am just aware of invitations for workshops by the ministry on the life skills education and training on inclusive education. In most cases, teacher educators are not engaged. Usually one or two representatives from the faculty are requested to participate in such workshops. There is never a time when the participants report back to the faculty; this information is rarely shared".

The observation that was made by this participant about lack of transparency on how teacher educators are identified to participate in the Ministry of Education and Training workshops was also expressed by another participant who claimed that: "The Ministry sometimes requests the Faculty to send representatives to attend training workshops or development of some policies. However, there is minimal openness regarding such endeavours." The responses of these participants indicate that the limited engagement of teacher educators in the workshops is not only practised by the Ministry of Education and Training. The Faculty of Education also lacks policies on teacher educators' participation the workshops, training events, and other related activities in the Ministry of Education and Training. According to these participants, how the Ministry of Education and Training involved teacher educators in the new reforms was not new but an established government practice. One participant emphasised this by saying: "Education policies in Lesotho [have been] top-down, as stakeholders [are] never consulted, nor are we involved in any new curriculum reforms".

Generally, this result indicates that teacher educators in Lesotho have not been actively or fully involved in the activities related to the school curriculum reforms. As such, these teacher educators displayed very limited knowledge about the intentions of the current curriculum reforms in Lesotho schools.

\subsection{How Teacher Educators Prepare In-Service Teachers for Reforms}

The participants were also asked how they had modified their teacher training practices to address the needs of the current curriculum reforms. In particular, they were asked about how the needs had influenced their formulation of learning objectives, choices of teaching strategies, teaching content, and learner assessment and feedback strategies. The responses revealed that teacher educators (6) had not orientated their classroom practices to the new reforms. In response, one participant confirmed as follows:

"I noticed during teaching practice observation and assessment that the University has been left behind with regard to curriculum reform. The University is training teachers that are not relevant to the needs of the new curriculum, in other words we are producing irrelevant teachers."

This finding resonated with the view that teacher educators knew very little about the current school reforms due to their limited involvement. As thus, teacher educators' practices were not aligned with the reform. 
One of the most interesting findings was that other participants (4) struggled to explain how they had changed their classroom practices to align with the reforms. They tried to create an impression that they were professionals who were attempting to align their own practices with the changes in the schools. Yet, their responses only demonstrated their limited knowledge about the new curriculum reforms and how far their teaching approaches were from those envisaged in the curriculum reforms. In what follows are some of the responses collected from a series of questions focusing on the change of practice regarding:

(1) formulation of teaching objectives.

Response 1: "I encourage learners to read widely and to be vigilant as the new curriculum is aimed to produce citizens that think out of the box."

Response 2: "I always urge students to ensure alignment of all the educational components ranging from objectives to content and teaching and assessment methods, I base this approach from a philosophy such as pragmatism which advocates the integrated approach to curriculum with the view to maximize."

Response 3: "Although the objectives of the course have not been modified, they are formulated to equip student-teachers with skills to use different forms of assessment in order to tailor to students' unique needs."

(2) organisation of content and design of learning tasks and assessment.

Response 1: "In the courses I teach, I never really get into such details. This aspect is yet to be explored. Maybe its lack of understanding of the new curriculum on my part."

Response 2: "I do not know. I train them to use different teaching strategies that accommodate individual learner's needs."

(3) selection of teaching and assessment strategies and resources.

Response 1: "I encourage teachers to use discovery learning and that is what I encourage teachers to do."

Response 2: "I usually help students to develop creativity by showing how they can integrate guidance and counselling in their varying teaching subjects. We have never agreed on this as the department. There is nothing yet that we are doing as the department."

(4) collection of classroom data from continuous and formative assessment to inform teaching

Response 1: "I have never touched this one. In the courses I teach I never really get into such details. This aspect is yet to be explored. Maybe its lack of understanding of the new curriculum on my part."

Response 2: "I have never done this and I don't even understand how it is done."

The above responses systematically demonstrate teacher educators' little knowledge about the reforms introduced in Lesotho schools and the extent of 
their ill-preparedness for teacher-training practices as the graduate training institution in the country.

\subsection{What Should be the Role Teacher Education in Reforms}

The participants were also asked about their views on what they considered as appropriate level of involvement for teacher educators in school reforms and how this could influence their professional practice. All the participants (6) were of the view that the Faculty of Education should be formally involved in the stages of the conceptualisation and formulation of the reforms. The following responses illustrate:

Response 1: "Under ideal conditions the Faculty should be involved at formulation stage, after a problem had been identified. Formulation stage would have helped the Faculty to revamp their programmes accordingly to accommodate the changes."

Response 2: "By being part of the state technocrats in formulation of the policy so that every stakeholder owns the policy."

Response 3: "Before the promulgation of the policy, our contributions could have helped a lot during the policy agenda setting and policy formulation stages. Staff from the department should have formed part of the team that developed policies as we have the technical knowhow in this area."

Response 4: "I think my department, as a foundation department, should have been involved from the very onset, i.e. at the inception stage of the curriculum......I think my department could have contributed fundamentally by finding the philosophical basis for the new curriculum and ensuring the alignment between the aim/objectives/outcomes and the content, the teaching and assessment methods, resources among others."

Generally, the participants viewed the formal engagement of the faculty by the government in the conceptualisation of all the school reforms as important They believed such an involvement could improve their understanding of the reforms and enable them to tailor their professional practices to the reforms.

All (6) the participants also pointed out that their involvement by the government should not be a once-off incident, nor should it be confined only to the reforms. They indicated that the involvement should be formal and continuous, coupled with constant communication between the faculty and the Ministry of Education and Training about educational challenges in Lesotho and the plans to address them. They also viewed that it was important that there is a strong relationship between the government and teacher education providers. From their point of view, their current status of knowledge about the reforms and their involvement in the implementation of these reforms in the classroom are the result of the limited communication between these two institutions. They also believed that if the government and the faculty could have clear and transparent policies about how teacher educators are involved in the matters of school curricula in Lesotho, 
this could have positive impact on how teacher educators prepare teachers for school reforms.

\section{Discussions}

Since the country's independence in 1966, all the regimes in Lesotho (governments) have been undertaking educational reforms to improve quality and relevance of education, and to address issues of school graduate unemployment. As already stated earlier, many of these reforms have been unsuccessful, with the blame falling mostly on teachers' lack of knowledge to implement the reforms. This study investigated the role of teacher educators in the preparation of in-service teachers for the reforms. The results of this study indicate that teacher educators in the institutions of higher learning in Lesotho have limited involvement in the formulation of these reforms. It is, therefore, unsurprising that the training provided for in-service teachers have been insufficient and not aligned with the changes needed for the successful implementation of the reforms.

The findings of this study suggest that graduates from institutions of higher learning in Lesotho who join a teaching profession are poorly equipped with the knowledge and skills needed to implement the current reforms in Lesotho schools. This view is based on Desimone's five feature model of professional development adopted by this study: (a) exposing teachers to the content, (b) actively engaging in-service teachers and giving them opportunities to observe how to the changes are implemented, and ensuring that (c) teaching aligns content, goals and learner activities with school curriculum and goals, and that teacher's knowledge and beliefs about national and school policies and the needs of their learners should be taken into account. The results show that the practices of teacher education are far from preparing teachers for the reforms along this model. Flower et al. (2016) and Maharajh et al. (2016) contend that the classroom poor performance of beginning teachers sometimes results from poor training which is mainly theoretical, and fails to align with the contextual needs of teachertrainees. The results of this study, therefore, demonstrate that teacher education, albeit being at the implementation stage, does not address the contextual needs of teacher-trainees, in terms of the national educational curriculum goals of Lesotho.

\section{Conclusion}

This study investigated the views of teacher educators in Lesotho about their involvement in the curriculum reforms in Lesotho schools. The main objectives of this study were to establish teacher educators': (1) knowledge about the current curriculum reforms in Lesotho schools; and (2) involvement in teacher preparation for the reforms, and (3) challenges that relate to preparing teachers for the reforms. Also the study (4) aimed to establish the implications of teacher educators' practices on teacher preparedness for the reforms. This qualitative study used a questionnaire to collect this information from six teacher educators in the department of educational foundations in one university in Lesotho. Data collected was analysed thematically. The results generated from this study have established that teacher educators had been involved in a limited way in the school curriculum reforms, and as a result, they have limited knowledge about the current school reforms. Further, their current pedagogical practices are not 
aligned with teachers' skills and knowledge needed to implement the reforms. These findings explain the results of the previous studies (Raselimo \& Mahao, 2015) that teachers are not implementing the new reforms because they lack knowledge and skills. The study indicate that teacher education received by the teachers is not contextualized, nor does it prepare them for the current curriculum reforms. While this study does not exclusively conclude that teachers' lack of knowledge and skills to implement the reforms is associated with their pre-service training, it recommends that teacher educators should be involved in meaningful curriculum reform activities to enable them be to better understand the reforms. Such in-depth understanding may influence their training practices mainly for the purpose of preparing pre- and in-service teachers. This study also recommends further investigation of the effectiveness of in-service training programmes that target the current reforms. The study should aim to find out whether those who received in-service training from government departments and other organisations have the necessary knowledge and skills and whether they are implementing the reforms successfully.

\section{References}

Abraham, O., \& Reginald, A. (2016). E-education: Changing the Mindsets of Resistant and Saboteur Teachers. Journal of Education and Practice, 7(16). https:// files.eric.ed.gov/fulltext/EJ1108660.pdf

African Development Fund. (2007). Lesotho - Education Quality Enhancement Project (Education III) - Appraisal Report. African Development Fund. https:// www.afdb.org/fileadmin/uploads/afdb/Documents/Project-andOperations/Lesotho__Education_Quality_Enhancement_Project_Education_III__Appraisal_Report.pdf

Akyeampong, K. (2017). Teacher Educators' Practice and Vision of Good Teaching in Teacher in Education Reform Context in Ghana. Educational Researcher (ER), 46(4), 194-203. https://doi.org/10.3102/0013189X17711907

Alsubaie, M. A. (2016). Curriculum Development: Teacher Involvement in Curriculum Development. Journal of Education and Practice, 7(9).

Ansell, N. (2002). "Of Course We Must Be Equal but...": Imagining Gendered Futures in Two Rural Southern African Secondary Schools. Geoforum, 33, 179-194. https://doi.org/10.1016/S0016-7185(01)00033-1

Carpenter, J. P., \& Green, T.D. (2017). Mobile Instant Messaging for Professional Learning: Educators' Perspectives On and Uses of Voxer. Teaching and Teacher Education, 68, 53-67. https://doi.org/10.1016/j.tate.2017.08.008

Chere-Masopha, J. (2018). Personal Landscapes of Teacher Professional Identities, and Digital Technology Adoption and Integration in Lesotho Schools. International Journal of Learning, Teaching and Educational Research, 17(3), 28-42. https:// doi.org/10.26803/ijlter.17.3.3

Chere-Masopha, J., \& Bennett, S. (2007). Using Teacher Professional Identity to Understand Classroom ICT. The International Journal of Learning, 14(7): 75-82. https://doi.org/10.18848/1447-9494/cgp/v14i07/45392

Chere-Masopha, J. (2011). Integrating Technology in Classroom Practices: The Influence of Teacher Professional Identities in Secondary Schools in Lesotho. Doctoral Thesis, University of Wollongong. Australia: Wollongong.

http://ijlter.org/index.php/ijlter 
Desimone L. M., \& Pak, K. (2017) Instructional Coaching as High-Quality Professional Development, Theory into Practice, 56(1), 3-12. http://doi.org10.1080/00405841.2016.1241947

Desimone, L. (2011). A Primer on Effective Professional Development. Phi Delta Kappan, 92, 68-71. https://doi.org/10.1177/003172171109200616

Dillon, D. R., Chang, Y. L., Rondeau, A. K., \& Kim, J. N. (2019). Teacher Educator Technology Integration Initiative: Addressing the Technology Preparation Gap. Journal of Technology and Teacher Education, 27(4), 527-554. https://eric.ed.gov/?id=EJ1247613

Education Sector Survey Task Force (Lesotho). (1982). The Education Sector Survey: Report of the Task Force, Maseru, Lesotho: National government publication.

Elo, S., Kääriäinen, M., Kanste O., Pölkki, T., Utriainen, K., \& Kyngäs, H. (2014). Qualitative Content Analysis: A Focus on Trustworthiness. SAGE Open. https://doi.org/10.1177/2158244014522633

Flower, A., McKenna, J. W., \& Haring, C. D. (2016). Behavior and Classroom Management: Are teacher Preparation Programs Really Preparing Our Teachers? Preventing School Failure: Alternative Education for Children and Youth, 65(3), 163-169. https://doi.org/10.1080/1045988X.2016.1231109

Falus, I., \& Orgoványi-Gajdos, J. (2016). New Aspects in European Teacher Education. Eger: Líceum Kiadó, ISBN 978-615-5621-25-3, 45-67

Harris, R., \& Graham, S. (2019): Engaging with Curriculum Reform: Insights from English History Teachers' Willingness to Support Curriculum Change. Journal of Curriculum Studies, 51(1), 43-61. https://doi.org/10.1080/00220272.2018.1513570

Howard, S. K. (2013). Risk-Aversion: Understanding Teachers' Resistance to Technology Integration. Technology, Pedagogy and Education, 22(3), 357-372. https://doi.org/10.1080/1475939X.2013.802995

Kahlke, R. (2014). Generic Qualitative Approaches: Pitfalls and Benefits of Methodological Mixology. International Journal of Qualitative Methods, 13, 37- 52. https://doi.org/ 10.1108/978-1-78560-651-920152019

Kosnik, C., \& Beck, C. (2008) In The Shadows: Non-Tenure-Line Instructors in Pre-Service Teacher Education. European Journal of Teacher Education, 31(2), 185-202. https://doi.org/10.1080/02619760802000214

Letseka, M. (1992). A Philosophical Outlook of Fundamental Issues in Education: Response to P. D. Soni. UNITRA Perspectives in Education, 1(4), 9-17.

Lim, C. P., \& Chan, B. C. (2007). In Teacher Education: Examining Pre-Service Teachers' Pedagogical Beliefs. Computers \& Education, 48(3), 474-494. https://doi.org/10.1016/j.compedu.2005.03.005

Lokesh R., Maharajh, T. N., \& Mbekelezi C. M. (2016). Teachers' Experiences of the Implementation of the Curriculum and Assessment Policy Statement (CAPS) in Three Primary Schools in KwaZulu Natal. Africa's Public Service Delivery $\mathcal{E}$ Performance Review, 4(3). https://doi.org/10.4102/apsdpr.v4i3

Lunenberg, M. S., Ramsarup P., Zeelen, J., Wedekind, V., Allais, S., Lotz-Sisitka, H., Monk, D., Openjuru, G., \& Russon, J. (2020). Vocational Education and Training for African Development: A Literature Review. Journal of Vocational Education $\mathcal{E}$ Training, 72(4), 465-487. https:/ / doi.org/10.1080/13636820.2019.1679969

Maharajh, L. R., Mbekelezi, T. N., \& Mkhize, C. (2016). Teachers' Experiences of the Implementation of the Curriculum and Assessment Policy Statement (CAPS) in Three Primary Schools in KwaZulu Natal. Africa's Public Service Delivery and Performance Review, 4(3):371. https:/ / doi.org/10.4102/apsdpr.v4i3.120 
Matšela, Z. A. (1979). The Indigenous Education of the Basotho and Its Implications for Educational Development in Lesotho. Doctoral thesis. University of Massachusetts Amherst.

MoET. (2009). Curriculum and Assessment Policy: Education for Individual and Social Development. Maseru: Ministry of Education and Training.

Muzvidziwa, V. N., \& Seotsanyana, M. (2002). Continuity, Change and Growth: Lesotho's Education System. Radical Pedagogy, 4(1) 1-17. https://radicalpedagogy.icaap.org/content/issue4_2/01_muzvidziwa.html.

Nhlapo, M., Moreeng B., \& Malebese, M. (2019). Challenges Facing Implementation of an Integrated Tourism Curriculum: The Experiences of Teachers in Lesotho. Journal of Education and Practice. 10(5).

Osamwonyi, E. F. (2016). In-Service Education of Teachers: Overview, Problems and the Way Forward. Journal of Education and Practice, 7(26). www.iiste.org.

Parsons, C. (2018). Constructivism and Interpretive Theory. In V. Lowndes, D. March \& G. Stocker (Eds.), Theory and Methods in Political Science (4th ed., pp. 75-91). Palgrave London: Macmilian.

Peyman, R., Gholam, R. K., \& Parviz, M. (2012). ESP In-Service Teacher Training Programs: Do They Change Iranian Teachers' Beliefs, Classroom Practices and Students' Achievements? Ibérica, 24, 261-282. https://www.redalyc.org/pdf/2870/287024476017.pdf

Raselimo, M., \& Mahao, M. (2013). The Lesotho Curriculum and Assessment Policy: Opportunities and Threats. South African Journal of Education. 35(1). https://doi.org/doi:10.15700/201503070025

Rodney, M. W. \& Elo, S. (1973). How Europe Underdeveloped Africa. Dar es Salaam: Tanzania Publishing House.

Salia-Bao, K. (1987). An Introduction to Curriculum Studies in Africa. London: MacMillan.

Selepe, C.M. (2016). Curriculum Reform in Lesotho: Teachers' Conceptions and Challenges. Doctoral Thesis. University of Freestate. http://wiredspace.wits.ac.za/handle/10539/20785

Shankar, P. R. (2014). Challenges in Implementing an Integrated Curriculum in Xavier University School of Medicine, Aruba. Education in Medicine Journal. 6(4). http://dx.doi.org/10.5959/eimj.v6i4.290

Schleicher, A. (2016). Teaching Excellence through Professional Learning and Policy Reform: Lessons from Around the World. OECD. http://dx.doi.org/10.1787/9789264252059-en

Seotsanayana, M., \& Muzvidizwa, V. N. (2002). Continuity, Change and Growth: Lesotho's Education System. Radical Pedagogy, 4(2).

Sinkovics, R.R.P. \& Alfoldi, E.A. (2012). Progressive Focusing and Trustworthiness in Qualitative Research. Management International Review. 52(6) 817-845. https://doi.org/10.1007/s11575-012-0140-5

Smuts, M. (2018). Bad Education: It Starts with How We Train Teachers. Daily Maverick. https://www.dailymaverick.co.za/opinionista/2018-04-04-bad-education-itstarts-with-how-we-train-teachers/

State University. (2020). Lesotho - History Background, Constitutional Legal Foundations, Educational System-overview, Preprimary Primary Education, Secondary Education. Education Encyclopedia. https://education.stateuniversity.com/pages/836/Lesotho-HistoryBackground.Html

Thelejane, T. E. (1990). Implementing Educational Policies in Lesotho. World Bank Discussion Papers No. 87. Africa Technical Department Series. World Bank, Washington, D.C. 
Van Bodegraven, D. B. (2015). Implementing Change: How, Why, and When Teachers Change Their Classroom Practices. Walden Dissertations And Doctoral Studies.

Vaismoradi, M., Turunen, H., \& Bondas, T. (2013). Content Analysis and Thematic Analysis: Implications for Conducting A Qualitative Descriptive Study. Nursing and Health Sciences, 15, 398-405. https://doi.org/doi:10.1111/nhs.12048.

Van Bodegraven, D.B. (2015). Implementing Change: How, Why, and When Teachers Change Their Classroom Practices. Walden Dissertations And Doctoral Studies. https://Scholarworks.Waldenu.Edu/Dissertations/1807/

Wong, H. (2004). Induction Programs That Keep New Teachers Teaching and Improving. NASSP Bulletin, 87(638), 5-27. https://doi.org/10.1177/019263650408863804.

World Bank. (2010). Lesotho - Education for All (EFA) Fast Track Initiative Catalytic Fund Grant Project (English). Washington, DC: World Bank. Group. http://documents.worldbank.org/curated/en/488081468056377395/Le sotho-Education-for-All-EFA-Fast-Track-Initiative-Catalytic-Fund-Grant-Project 